\title{
Left ventricular systolic function in sickle cell anaemia: an echocardiographic evaluation in adult Nigerian patients.
}

\author{
Emmanuel Ejim, Nelson Oguanobi
}

University of Nigeria Teaching Hospital, Enugu, Medicine

\begin{abstract}
:
Background: Reliable diagnostic measures for the evaluation of left ventricular systolic performance in the setting of altered myocardial loading characteristics in sickle cell anaemia remains unresolved.

Objective: The study was designed to assess left ventricular systolic function in adult sickle cell patients using non-invasive endsystolic stress - end-systolic volume index ratio.

Methods: A descriptive cross sectional comparative study was done using 52 patients recruited at the adult sickle cell anaemia clinic of the University of Nigeria Teaching Hospital Enugu. An equal number of age and sex-matched healthy volunteers served as controls. All the participants had haematocrit estimation, haemoglobin electrophoresis, as well as echocardiographic evaluation.

Result: The mean age of the patients and controls were $23.93 \pm 5.28$ (range 18-42) and $24.17 \pm 4.39$ (range 19 -42) years respectively, $(t=0.262 ; \mathrm{p}=.794)$. No significant difference was seen in estimate of fractional shortening, and ejection fraction. The cardiac out-put, cardiac index and velocity of circumferential shortening were all significantly increased in the cases compared with the controls. The end systolic stress - end systolic volume index ratio (ESS/ESVI) was significantly lower in cases than controls. There were strong positive correlation between the ejection phase indices (ejection fraction and fractional shortening) and end systolic stress and ESS/ESVI.

Conclusion: The study findings suggest the presence of left ventricular systolic dysfunction in adult sickle cell anaemia. This is best detected using the loading-pressures independent force-length relationship expressed in ESS/ESVI ratio.

Keywords: Left ventricular systolic function, sickle cell anaemia, echocardiographic evaluation, adult Nigerian patients.

DOI: http://dx.doi.org/10.4314/ahs.v16i3.16

Cite as: Ejim E, Oguanobi N. Left ventricular systolic function in sickle cell anaemia: an echocardiographic evaluation in adult Nigerian patients. Afri Health Sci 2016;16(3): 755-765. DOI: http:// dx.doi.org/10.4314/abs.v16i3.16
\end{abstract}

\section{Introduction}

Ejection phase indices have been used commonly as measures of left ventricular systolic function ${ }^{1,2}$. These measures are highly dependent on and influenced by myocardial loading conditions as well as heart rate, both of which are abnormal in sickle cell anaemia ${ }^{3,4}$. Use of these indices of systolic function in this population may explain the broad spectrum of results and apparent inconsistencies documented in the literature $\mathrm{r}^{5,6,7,8,9}$.

\footnotetext{
Corresponding author:

Emmanuel Ejim,

University of Nigeria Teaching Hospital, Enugu, Medicine

Email: dremmaejim@hotmail.com
}

A number of studies have examined the use of the end systolic force-length relationship to characterize myocardial contractility ${ }^{10,11,12}$. This relationship can be plotted using LV end-systolic pressure or wall stress as the force measurement and end-systolic LV volume, circumference or diameter as the length measurement. When force is expressed as wall stress, the myocardial after-load and contractile state can be readily compared in ventricles of different sizes and wall thicknesses, because these variables are included in the stress calculation. These indices of myocardial performance which are independent of loading conditions have been shown to be more sensitive in the evaluation of left ventricular systolic function in sickle cell anaemia ${ }^{4,10}$.

Although sickle cell anaemia is the commonest haemoglobinopathy in sub-Saharan Africa, and is associated with increased cardiac morbidity, descriptive data on end 
systolic stress in normal and abnormal left ventricles are limited $^{13}$. Therefore, the present study was designed to provide an assessment of left ventricular systolic function in adult sickle cell patients using non-invasive end-systolic stress-end systolic volume index ratio and to compare this value with simultaneous measurement of ejection phase indices.

\section{Methods}

From February 2004 to July 2005, a descriptive cross sectional case-control study was done using 52 cases recruited at the adult sickle cell anaemia clinic of the University of Nigeria Teaching Hospital Enugu, Nigeria. The inclusion criteria for the cases included; haemoglobin genotype SS on haemoglobin electrophoresis, age $>18$ years, absence of any form of crises in the preceding four weeks informed consent to participate in the study, and clinic visit within the 18 months period of study. All the cases who met the inclusion criteria were recruited.

An equal number of age and sex matched healthy volunteers served as controls. The eligibility criteria for the controls were: HbAA genotype, absence of congenital or acquired heart disease, consent to participate in the study, absence of pregnancy and/or inter-current illness, haematocrit level greater than $30 \%$. All the participants had haematocrit estimation, haemoglobin electrophoresis, as well as echocardiographic evaluation using Hewlett Packard Sonos2000 echocardiography machine with $3.7 \mathrm{MHz}$ transducer. Systemic blood pressure was measured with an Accoson Mercury sphygmomanometer on the right arm, with the subjects in sitting positions, and the average of 3 readings used. The following measurements were taken in the standard positions as recommended by the American Society of Echocardiography ${ }^{14,15}$. Aortic root diameter (Ao), left atrial dimension (LAD), left ventricular end diastolic diameter (LVEDD), left ventricular end systolic diameter (LVESD), right ventricular dimensions (RVD), septal wall thickness (SWT), posterior wall thickness (PWT) were measured with M-mode. Fractional shortening (FS) (determined by EDD-ESD/EDD), left ventricular mass (LVM) using the standard convention, and left ventricular mass index (LVMI) (derived by dividing LVM by body surface area) were derived from the M-mode measurements. End diastolic volume, and end systolic volume using the modified Simpson's method, stroke volume, end systolic volume index (ESVI)(derived by dividing end systolic volume by body surface area), cardiac output, cardiac index, ejection fraction, were derived from 2-dimensional B-mode imaging. Anterior mitral valve E-point to septal separation (ES) and EF slope were also measured.

Left Ventricular wall stress (Left ventricular end-systolic stress LVESS) was determined using the angiographically Validated method of Grossman and co-workers; (0.334 PxLVID/PWT [1 + PWT/LVID]). The value is expressed in $\mathrm{kdyn} . \mathrm{cm}^{-2}$, where $\mathrm{P}=$ the left ventricular systolic pressure, LVID = LV diameter in systole and PWT $=\mathrm{LV}$ posterior wall thickness in systole ${ }^{16}$. The mean arterial systolic blood pressure was used as the left ventricular systolic pressure, while the mean arterial blood pressure was calculated with the formula MAP $=$ DBP $+1 / 3 \mathrm{PP}^{17}$; where $\mathrm{MAP}=$ mean arterial blood pressure, $\mathrm{DBP}=$ diastolic blood pressure, and $\mathrm{PP}=$ pulse pressure.

The total systemic resistance index was calculated as the ratio of mean arterial blood pressure and cardiac index ${ }^{7}$ and is expressed as dynes.sec. $\mathrm{cm}^{-5} \cdot \mathrm{m}^{2}$

\section{Data analysis}

Data is presented as means \pm standard deviation for continuous variables and as proportions for categorical variables. Comparison of continuous variables between the sickle cell disease patients group and the control group were made with independent Student's t-test. For discrete variables distribution between groups were compared with Chi- square test and Fishers exact test as appropriate (where an expected cell is less than 5). Multivariate Pearson's correlation analysis was used to examine the relationship between measures of systolic function and clinical and echocardiographic variables. The relationship was subsequently evaluated by means of scatter-plots and regression models. All statistical analyses were carried out using the Statistical Packages for Social Sciences (SPSS Inc. Chicago Illinois) software version 11.0 and EPi-Info version 3.4. Statistical tests with probability values less than 0.05 were considered statistically significant.

\section{Results}

The mean age of the patients and controls were $23.93 \pm$ 5.28 (range 18-42) and $24.17 \pm 4.39$ (range $19-42$ ) years respectively (Table 1$)$. 


\section{Table 1: Age, gender and anthropometric data}

\begin{tabular}{|c|c|c|c|c|}
\hline PARAMETERS & $\begin{array}{l}\text { SCA } \\
\text { Mean (SD) }\end{array}$ & $\begin{array}{l}\text { CONTROLS } \\
\text { Mean (SD) } \\
\end{array}$ & T-TEST & P-VALUE \\
\hline Age (years) & $23.93(5.28)$ & $24.17(4.39)$ & -.262 & .794 \\
\hline \multicolumn{5}{|l|}{$\begin{array}{l}\text { Gender } \\
\{\text { frequency }(\%)\}\end{array}$} \\
\hline Male & 26 & 22 & & \\
\hline Female & 28 & 30 & 0.365 & $0.546^{a}$ \\
\hline Total & 54 & 52 & & \\
\hline Weight(kg) & $54.56(8.63)$ & $65.44(10.06)$ & -5.989 & $.000^{*}$ \\
\hline Height(m) & $1.65(0.13)$ & $1.67(0.12)$ & -1.054 & .294 \\
\hline $\begin{array}{l}\text { Body surface } \\
\text { area }\left(\mathrm{m}^{2}\right)\end{array}$ & $1.58(0.16)$ & $1.75(0.17)$ & -5.347 & $.000^{*}$ \\
\hline $\begin{array}{l}\text { Body mass } \\
\text { index }\left(\mathrm{Kg} / \mathrm{m}^{2}\right)\end{array}$ & $19.68(2.62)$ & $23.11(2.84)$ & -6.461 & $.000^{*}$ \\
\hline
\end{tabular}

Key: *Statistically significant, ${ }^{\mathrm{a}}=\mathrm{Chi}$-square, $\mathrm{SCA}=$ sickle cell anaemia, $\mathrm{SD}=$ standard deviation.

There were no statistically significant age and gender dif- lower diastolic blood pressure, lower mean arterial blood ferences in patients and controls. The haematocrit, pulse pressure and increased pulse pressure. The various indiand blood pressure indices are summarized in table 2. ces of left ventricular systolic function are compared in Significant findings in the patients were higher pulse rate, table 3. 
Table 2: Pulse and Blood pressure indices

\begin{tabular}{|c|c|c|c|c|}
\hline PARAMETERS & $\begin{array}{c}\text { SCA } \\
\text { MEAN (SD) }\end{array}$ & $\begin{array}{r}\text { CONTROLS MEAN } \\
\text { (SD) }\end{array}$ & T-TEST & P-VALUE \\
\hline $\begin{array}{l}\text { Pulse rate } \\
\text { (beat } / \mathrm{min} \text { ) }\end{array}$ & $85.17(13.51)$ & $76.81(10.00)$ & 3.95 & $<.001^{*}$ \\
\hline $\begin{array}{l}\text { Brachial systolic } \\
\mathrm{BP}(\mathrm{mmHg})\end{array}$ & $121.65(17.85)$ & $119.04(11.81)$ & .884 & 0.379 \\
\hline $\begin{array}{l}\text { Brachial diastolic } \\
\operatorname{BP}(\mathrm{mmHg})\end{array}$ & $70.20(10.61)$ & $77.19(8.18)$ & 3.787 & $<.001^{*}$ \\
\hline $\begin{array}{l}\text { Brachial pulse } \\
\text { pressure }(\mathrm{mmHg})\end{array}$ & $51.44(14.63)$ & $41.85(10.67)$ & 3.848 & $0.001^{*}$ \\
\hline $\begin{array}{l}\text { Mean brachial } \\
\text { arterial } \mathrm{BP}(\mathrm{mmHg})\end{array}$ & $87.35(11.56)$ & $91.14(8.11)$ & 1.946 & $<.054^{*}$ \\
\hline Haematocrit (\%) & $24.07(3.10)$ & $38.65(1.97)$ & 30.589 & $<.001^{\star}$ \\
\hline
\end{tabular}

Key: *Statistically significant, SCA=sickle cell anaemia, SD=standard deviation.

Table 3: Indices of left ventricular systolic function

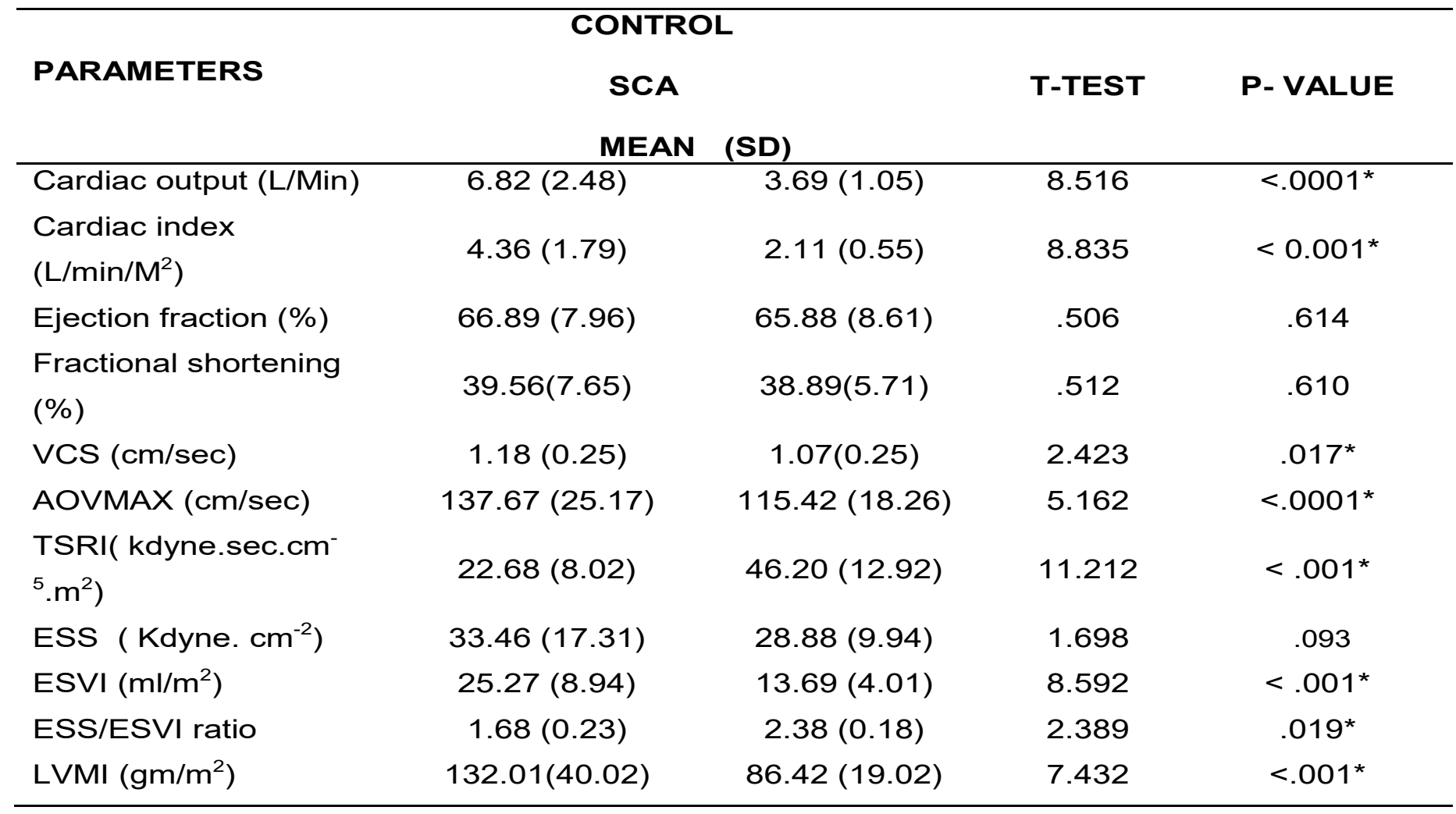

Key:*statistically significant, ESS= left ventricular end systolic stress, ESVI= left ventricular end systolic volume index, LVMI= left ventricular mass index. AOVMAX = peak aortic systolic velocity, $V C S=$ velocity of circumferential shortening, $\mathrm{SCA}=$ sickle cell anaemia, $\mathrm{SD}=$ standard deviation.

No significant difference was seen in estimate of fractional shortening, and ejection fraction. The cardiac out-put, cardiac index and velocity of circumferential shortening were all significantly increased in the patients compared with the controls. The end systolic stress end systolic volume index ratio (ESS/ESVI) was significantly 
lower in patients than controls; $(1.68 \pm 0.23$ and $2.38 \pm$ 0.18 respectively, $t=2.389 ; \mathrm{p}=.019)$. The total systemic resistance index was also significantly lower in the patients, $(22.68 \pm 8.02 ; 46.20 \pm 12.92, \mathrm{t}=11.212, \mathrm{p}=<.001)$.
Multivariate correlation analysis revealed strong positive correlation between the ejection phase indices (ejection fraction and fractional shortening) and end systolic stress and ESS/ESVI (tables 4 and 5).

Table 4: Multivariate correlation of clinical and echocardiographic variables in sickle cell anaemia.

\begin{tabular}{|c|c|c|c|c|c|c|c|c|c|c|c|c|c|c|c|}
\hline & & age & pulse & SBP & DBP & weight & BSA & BMI & pulse pressure & MAP & ESS & ESVI & ESS/ESVI & LVMI & TSRI \\
\hline \multirow[t]{2}{*}{$\begin{array}{l}\text { Fractional } \\
\text { Shortening }\end{array}$} & $\begin{array}{l}\text { Pearson } \\
\text { Correlation }\end{array}$ & & -.086 & .137 & .126 & .083 & .017 & & & .147 & $.633^{* *}$ & -.180 & & -.161 & .150 \\
\hline & Sig. (2-tailed) & .390 & .536 & .324 & .365 & .550 & .902 & .255 & .587 & .288 & .000 & .196 & .007 & .248 & .278 \\
\hline \multirow[t]{2}{*}{ Cardiac index } & $\begin{array}{l}\text { Pearson } \\
\text { Correlation }\end{array}$ & -.098 & $.570^{* *}$ & .213 & .173 & & $-.333^{*}$ & -.070 & .134 & .215 & -.039 & .162 & -.190 & $.489^{* *}$ & $-820^{* *}$ \\
\hline & Sig. (2-tailed) & .481 & .000 & .122 & .212 & .040 & .015 & .615 & .333 & .118 & .780 & .248 & .172 & .000 & .000 \\
\hline \multirow[t]{2}{*}{ Ejection fraction } & $\begin{array}{l}\text { Pearson } \\
\text { Correlation }\end{array}$ & .136 & .148 & .057 & -.160 & -.224 & $-.304^{*}$ & -.129 & .186 & -.069 & .235 & $-.655^{* *}$ & $.505^{* *}$ & .271 & $-.331^{*}$ \\
\hline & Sig. (2-tailed) & .325 & .287 & .681 & .247 & .103 & .027 & .353 & .177 & .622 & .087 & .000 & .000 & .050 & .014 \\
\hline \multirow[t]{2}{*}{ VCF } & $\begin{array}{l}\text { Pearson } \\
\text { Correlation }\end{array}$ & .049 & $.280^{*}$ & .161 & .222 & -.217 & -.208 & -.188 & .035 & .218 & $.315^{*}$ & -.054 & .186 & .171 & -.006 \\
\hline & Sig. (2-tailed) & .724 & .040 & .246 & .107 & .115 & .135 & .174 & .800 & .113 & .020 & 699 & .182 & .220 & .963 \\
\hline \multirow[t]{2}{*}{ AoVmax } & $\begin{array}{l}\text { Pearson } \\
\text { Correlation }\end{array}$ & -.185 & .139 & .215 & .011 & -.189 & -.213 & -.250 & .254 & .117 & -.094 & -.008 & -.166 & .239 & -.155 \\
\hline & Sig. (2-tailed) & .180 & .316 & .119 & .936 & .171 & .125 & .068 & .064 & .398 & .499 & .955 & .234 & .085 & .265 \\
\hline \multirow[t]{2}{*}{ ESS } & $\begin{array}{l}\text { Pearson } \\
\text { Correlation }\end{array}$ & .211 & .052 & $.435^{* *}$ & .148 & .130 & .062 & .093 & $.423^{* *}$ & $.314^{*}$ & 1 & -.232 & $.669^{* *}$ & -.005 & .160 \\
\hline & Sig. (2-tailed) & .126 & .709 & .001 & .284 & .350 & .658 & .502 & .001 & .021 & & .094 & .000 & .969 & .249 \\
\hline \multirow[t]{2}{*}{ ESVI } & $\begin{array}{l}\text { Pearson } \\
\text { Correlation }\end{array}$ & -.164 & -.094 & .078 & .228 & .232 & .269 & .158 & -.071 & .180 & -.232 & 1 & $-.628^{* *}$ & .035 & -.169 \\
\hline & Sig. (2-tailed) & .242 & .502 & .580 & .100 & .095 & .051 & .259 & .614 & .198 & .094 & & .000 & .805 & .227 \\
\hline \multirow[t]{2}{*}{ ESS/ESVI } & $\begin{array}{l}\text { Pearson } \\
\text { Correlation }\end{array}$ & .384 & .085 & .048 & -.232 & -.113 & -.137 & -.075 & .227 & -.117 & $.669^{* *}$ & $-.628^{* *}$ & 1 & -.097 & .222 \\
\hline & Sig. (2-tailed) & .005 & .546 & .732 & .094 & .422 & .329 & .592 & .102 & .403 & .000 & .000 & & .488 & .109 \\
\hline \multirow[t]{2}{*}{ LVMI } & $\begin{array}{l}\text { Pearson } \\
\text { Correlation }\end{array}$ & -.004 & $.298^{*}$ & $.314^{*}$ & .258 & $-.354^{* *}$ & $-.342^{*}$ & $-.343^{*}$ & .195 & $.319^{*}$ & -.005 & .035 & -.097 & 1 & $-.283^{*}$ \\
\hline & Sig. (2-tailed) & .978 & .030 & .022 & .062 & .009 & .012 & .012 & .161 & .020 & .969 & .805 & .488 & & .040 \\
\hline \multirow[t]{2}{*}{ TSRI } & $\begin{array}{l}\text { Pearson } \\
\text { Correlation }\end{array}$ & .102 & $-.487^{* *}$ & .095 & .139 & .169 & .231 & .015 & .015 & .134 & .160 & -.169 & .222 & $-.283^{*}$ & 1 \\
\hline & Sig. (2-tailed) & .464 & .000 & .493 & .316 & .221 & .096 & .916 & .912 & .333 & .249 & .227 & .109 & .040 & \\
\hline \multirow[t]{2}{*}{ ESD } & $\begin{array}{l}\text { Pearson } \\
\text { Correlation }\end{array}$ & -190 & .164 & .006 & .047 & -.047 & .025 & -.108 & -.027 & .032 & $-.688^{* *}$ & $.388^{* *}$ & $-.646^{* *}$ & $-.325^{*}$ & $-.274^{*}$ \\
\hline & Sig. (2-tailed) & .168 & .236 & .967 & .737 & .736 & .862 & .436 & .847 & .820 & .000 & .004 & .000 & .018 & .045 \\
\hline
\end{tabular}

Key: **statistically significant $<.01$, *significant <.05, ESS= left ventricular end systolic stress, ESVI= left ventricular end systolic volume index, LVMI= left ventricular mass index. $\mathrm{AOVMAX}=$ peak aortic systolic velocity, $\mathrm{VCS}=$ velocity of circumferential shortening, $\mathrm{MAP}=$ mean arterial pressure, $\mathrm{SBP}=$ systolic blood pressure, $\mathrm{DBP}=$ diastolic blood pressure, $B S A=$ body surface area. 
Table 5: Relationship between ESS/ESVI and Ejection indices of systolic function; regression model summary.

\begin{tabular}{|c|l|l|l|l|l|}
\hline \multirow{2}{*}{ Relationship/Model } & \multicolumn{5}{|c|}{ Model Summary/ Parameter estimates } \\
\cline { 2 - 6 } & R & B & Constant & F & Significance \\
\hline $\begin{array}{l}\text { ESS/ESVI and FS in } \\
\text { SCA }\end{array}$ & & & & & \\
\hline Linear & .366 & 0.080 & -1.485 & 7.907 & $.007^{*}$ \\
\hline Logarithm & .360 & 2.994 & -.9 .273 & 7.605 & $.008^{*}$ \\
\hline Quadratic & .368 & 0.030 & -0.517 & 3.904 & $.027^{*}$ \\
\hline $\begin{array}{l}\text { ESS/ESVI and FS in } \\
\text { Controls }\end{array}$ & & & & & \\
\hline Linear & .546 & 0.124 & -2.446 & 21.265 & $.000^{*}$ \\
\hline Logarithm & .535 & 4.527 & -14.140 & 20.034 & $.000^{*}$ \\
\hline Quadratic & .555 & -0.143 & 2.533 & 10.928 & $.000^{*}$ \\
\hline $\begin{array}{l}\text { ESS/ESVI and EF in } \\
\text { SCA }\end{array}$ & & & & & \\
\hline Linear & .505 & 0.108 & -5.489 & 17.430 & $.000^{*}$ \\
\hline Logarithm & .487 & 6.993 & -27.620 & 15.879 & $.000^{*}$ \\
\hline Quadratic & .557 & -0.581 & 17.645 & 11.237 & $.000^{*}$ \\
\hline $\begin{array}{l}\text { ESS/ESVI and EF in } \\
\text { Controls }\end{array}$ & & & & & \\
\hline Linear & .018 & -0.020 & 30.223 & 0.017 & .897 \\
\hline Quadratic & .505 & -0.390 & 12.231 & 8.587 & $.001^{*}$ \\
\hline Cubic & .510 & -0.180 & 8.264 & 8.619 & $.001^{*}$ \\
\hline
\end{tabular}

This relationship was further evaluated by means of scatter plots and subsequently by regression analysis. The suitability of various regression models for explanation of variations in the dependable variables were examined using ANOVA, while the strength of the relationship was determined by the parameter estimates and model sum- mary report (table 6). The relevant regression models are summarized in table 5 and the actual plots presented in figures 1-4. Regular linear models seem to explain the relationship between ESS/ESVI and ejection phase indices in sickle cell anaemia patients (Figures 1 and 3). The relationship in the controls were less predictable and irregular (table 5, Figures 2 and 4). 
Figure 1:ESSIESVI ratio and Fractional Shortening relationship in sickle cell patients; Regression models.

\section{ESSESV ratio}

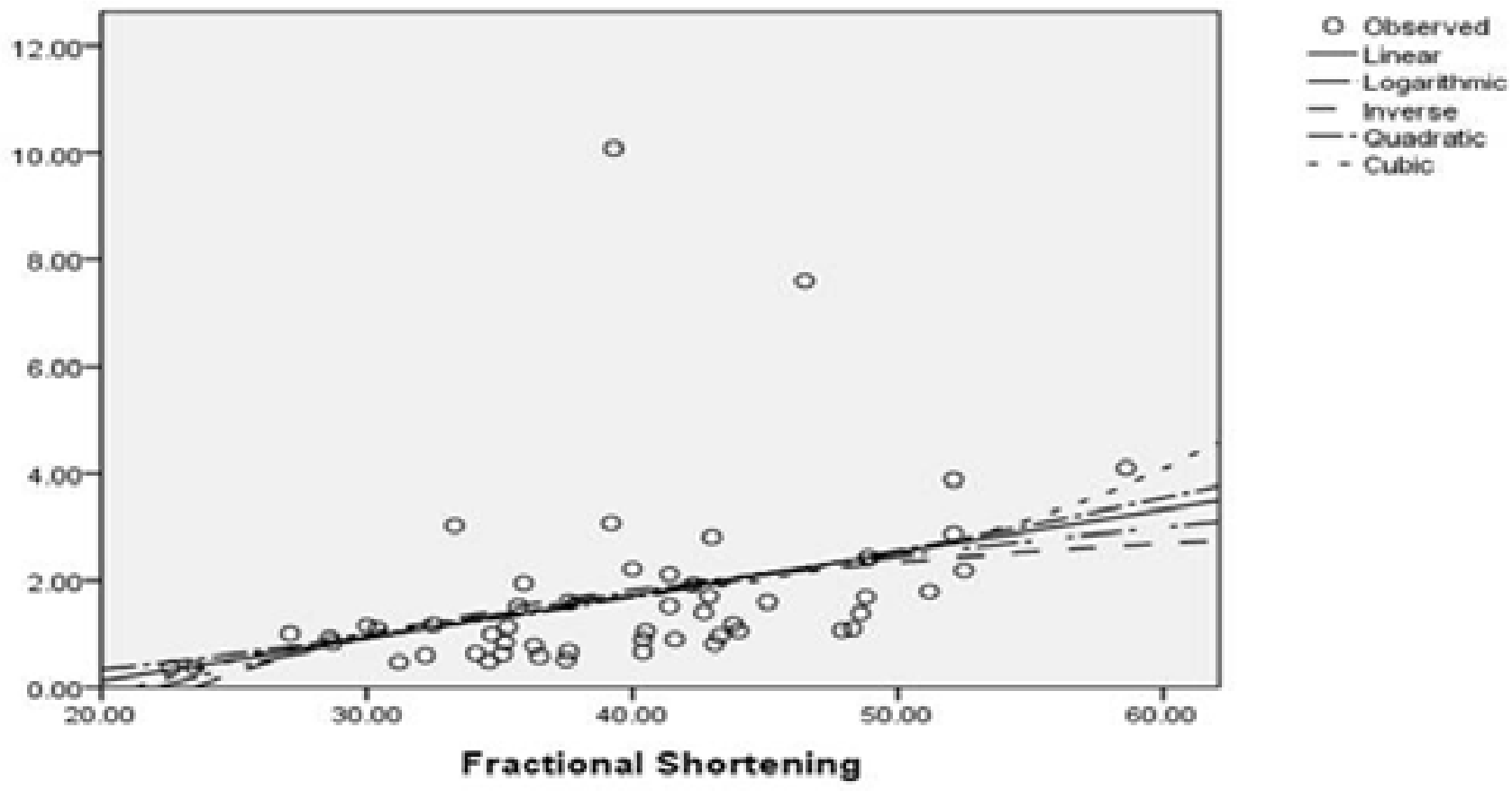

Figure 2:ESSIESVI ratio and Fractional Shortening relationship in the controls; Regression models.

\section{ESSIESVI ratio}
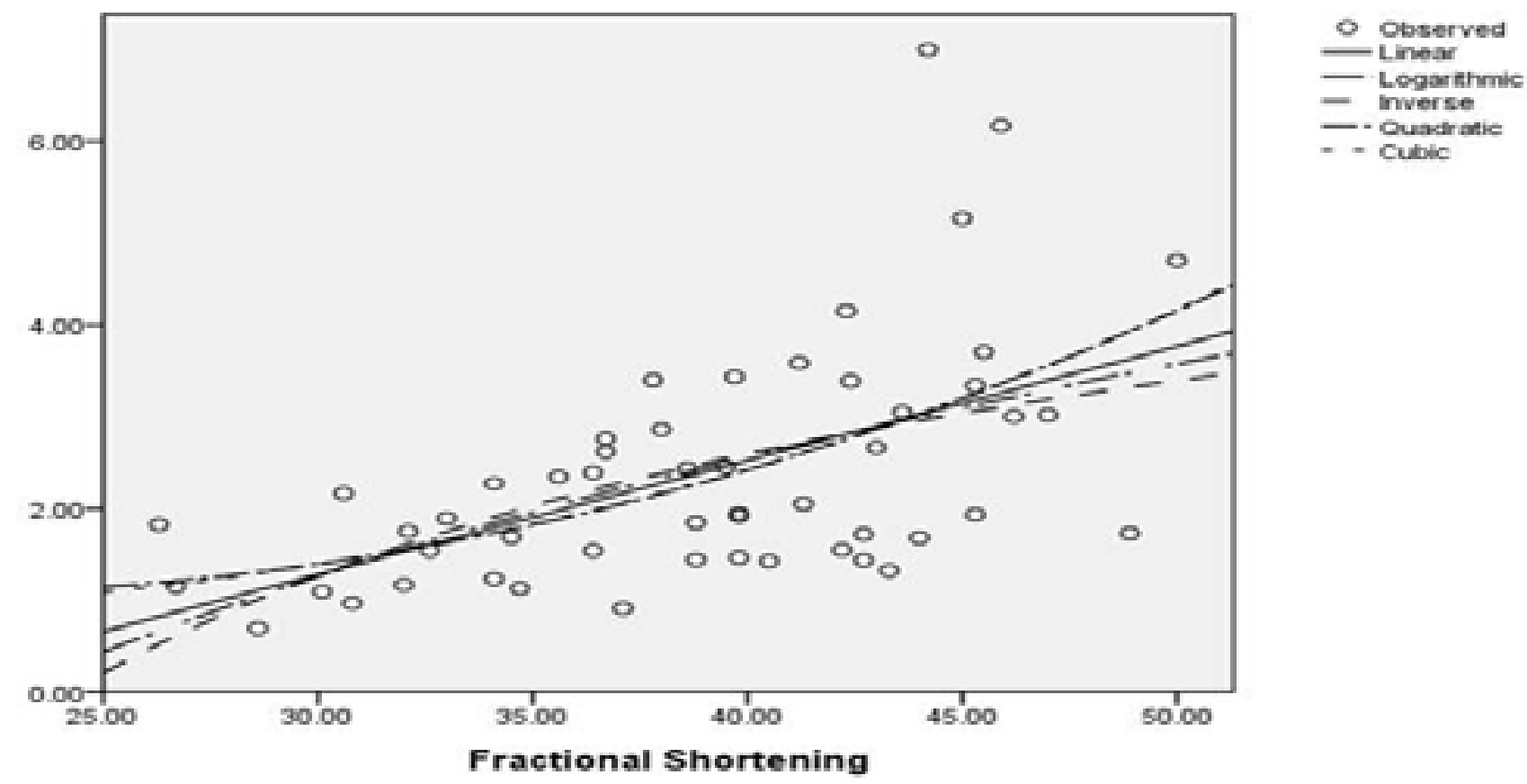

- Ouadir antic

Fractional Shortening 
Figure 3:ESSIESVI ratio and Ejection Fraction relationship in sickle cell patients; Regression models.

\section{ESSIESVI ratio}
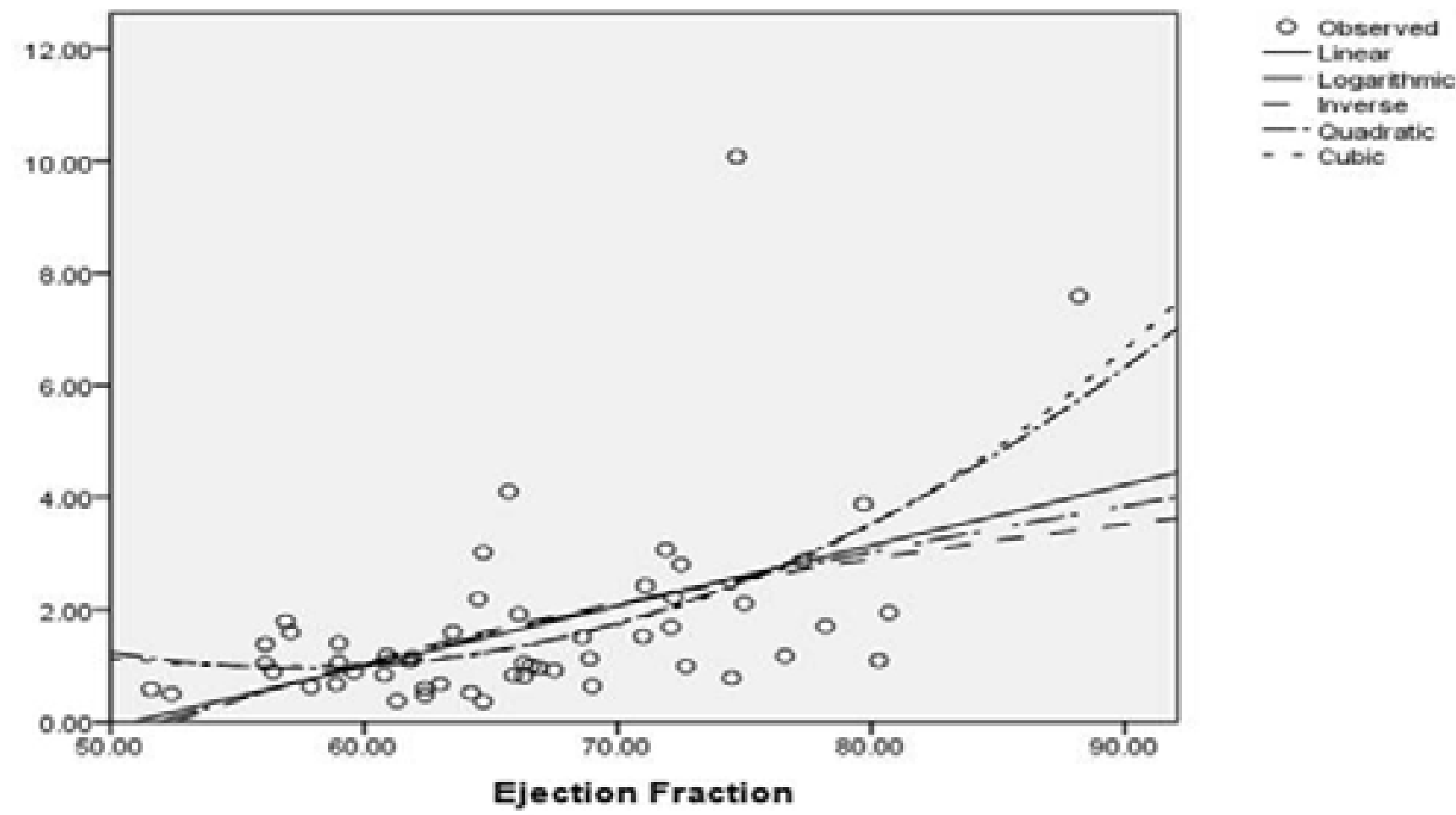

Figure 4:ESS/ESVI ratio and Ejection Fraction relationship in the controls; Regression models.

\section{ESSIESVI ratio}
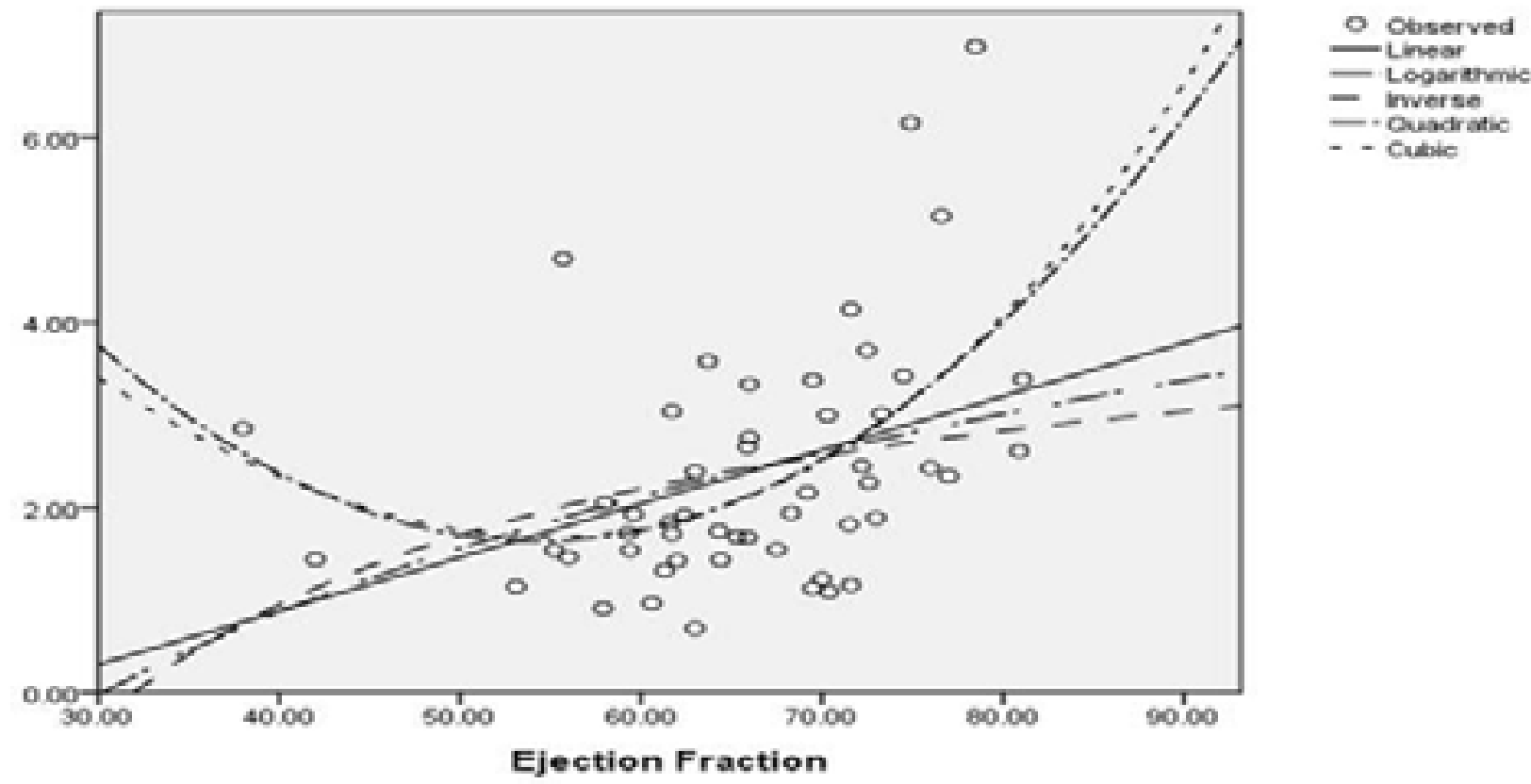


\section{Discussion}

The evaluation of left ventricular systolic function in sickle cell anaemia has yielded inconsistent results, probably due to the differences in patient's selection criteria and the indices of systolic function employed in the studies. Ejection phase indices are commonly used as measures of left ventricular systolic function. However, it has been observed that alterations in the loading characteristics of the heart in patients with chronic anaemia affect the ejection performance of the heart ${ }^{4,5}$.

Using ejection phase indices as measures of systolic function, this study did not demonstrate any significant difference in ejection fraction, fractional shortening and velocity of circumferential shortening between cases and controls. This is in keeping with findings from previous studies $^{7,8}$. Adebiyi et $\mathrm{al}^{7}$ found no significant difference in the left ventricular systolic function at rest between sickle cell patients and controls using ejection phase indices. The cases were aged 16years and above, but their mean age was not specified. Similarly, Covitz et $\mathrm{al}^{8}$ found normal left ventricular systolic function in stable sickle cell anaemia patients as indicated by normal fractional shortening, and systolic time intervals.

In contrast to the above findings, some researchers reported abnormal left ventricular function in sickle cell patients.

Left ventricular performance determined by echocardiography in 44 black children with sickle cell anaemia and a control group of 28 normal black children of comparable age by Rees et $\mathrm{al}^{5}$ revealed statistically significant differences between the children with sickle cell anaemia and the normal group in left ventricular ejection fraction, cardiac index, mean circumferential fiber shortening velocity, and the percentage of shortening of left ventricular minor axis dimension. These findings consistent with left ventricular systolic function have been corroborated by the report of Balfour and colleagues ${ }^{6}$ who also observed that left ventricular function became increasingly abnormal with age, suggesting that left ventricular function deteriorated with time. It is worth noting that most of the studies reporting abnormal systolic function in sickle cell patients were conducted in children whereas most of adult studies reported normal systolic function. The conflicting results of these studies have been attrib- uted to different selection factors in the study groups, an improvement in left ventricular function with age or a high mortality among children with abnormal left ventricular function so that such patients do not appear in adult samples.

However, the validity of using ejection phase indices as indicators of left ventricular function under the altered loading condition in chronic anaemia has been challenged ${ }^{4}$. Using the end systolic stress-dimension relationship as an index of contractile function independent of loading pressures, this study demonstrated a statistically significant reduction in the end systolic stress-end systolic dimension ratio index in sickle cell patients compared with controls. This finding is consistent with systolic dysfunction. End systolic wall stress (ESWS) is an important determinant of ventricular shortening, and reduction in wall stress facilitates ventricular emptying ${ }^{10}$. Ejection fraction is affected by changes in preload and afterload. End systolic volume is relatively independent of preload and varies linearly with afterload ${ }^{11,12}$. A higher ESWS/ ESVI ratio would indicate relatively greater left ventricular shortening at a given after-load, and a lower ESWS/ ESVI would indicate less shortening for a given after-load and thus relatively poorer left ventricular function.

Adebiyi et $\mathrm{al}^{7}$, in a study in Ibadan, Nigeria on thirty sickle cell patients (aged $>16$ years) using similar indices, observed that the end systolic stress-end systolic dimension ratio although lower in sickle cell patients was not significantly different from that of the controls. This discrepancy could be explained by the smaller sample size and the relatively younger patients in the latter study, especially in the light of the findings by this study of a negative correlation between the pressure indices of systolic function and age.

The unreliability of ejection phase indices in the determination of left ventricular function in patients with sickle cell anaemia is due to their inability to accurately quantify the relative contribution of each of the variables that affect left ventricular pump function. These variables include; myocardial contractile state, end-diastolic myocardial length, afterload and LV myocardial mass ${ }^{11}$. In sickle cell anaemia, preload is increased due to left ventricular hypertrophy and cardiac chamber enlargement second- 
ary to chronic anaemia and hyper-dynamic circulation ${ }^{18}$. The after-load is reduced due to decrease in peripheral resistance and increased heart rate. These changes tend to normalize ejection phase indices, even in the presence of left ventricular dysfunction ${ }^{4}$. In our study, the role of the preload and after load variables appear to be quite remarkable in view of the findings of reduced total systemic resistance index, higher heart rate, and elevated left ventricular mass and left ventricular dimensions. Regression plot of the ESS/ESVI and ejection phase indices indicated strong linear relationship in sickle cell patients, a feature that was not evident in the controls. This observation indicates the discriminatory value of the pressure indices of systolic function in the evaluation of patients with altered loading conditions as seen in sickle cell anaemia, rather than in the generality of patients.

The ESS/ESVI ratio has been shown to be more sensitive than ejection fraction or other hemodynamic variables in predicting surgical outcome in symptomatic patients with chronic mitral regurgitation ${ }^{12}$.

In spite of its accuracy in assessing systolic function, the use of ESS/ESVI is challenged by some limitations. A major challenge to the application of this measure is the lack of data on the acceptable normal range and cut-off values for diagnosis of left ventricular systolic dysfunction. Secondly, the ESS/ESVI is subject to a wide range of fluctuations in response to changes in sympathetic drive.

\section{Conclusion}

The findings suggest the presence left ventricular systolic dysfunction in adult sickle cell anaemia. This is best detected using the loading-pressures independent forcelength relationship expressed in ESS/ESVI ratio.

\section{Coflict of interest}

None to declare.

\section{References}

1. Quinones MA, Gash W, Alexander J K. Echocardiographic assessment of left ventricular function with special reference to normalized velocities. Circulation 1974; 50: 42 - 57. PubMed

2. Teicholz LE, Krevlen T, Herman MV, Gorlin R. Prob- lems in echocardiographic volume determinations: echocardiographic correlations in the presence or absence of a synergy. Am J Cardiol 1976;37: 7 - 11.

3. Varat MA, Adolph RJ, Fowler NO. Cardiovascular effects of anaemia. Am. Heart J. 1972; 83: 415 - 426. PubMed

4. Dennenberg BS, Criner G, Jones R, Spann JF. Cardiac function in sickle cell anaemia. Am J Cardiol 1983; 51: 1674-1678.

5. Rees AH, Stefadouros MA, Strong WB, et al. Left ventricular performance in children with homozygous sickle cell anaemia. Br Heart J 1978; 40: 690-696 PubMed .

6. Balfour IC, Covitz W, Davis H, Rao PS, Strong WB, Alpert BS. Cardiac size and function in children with sickle cell anaemia. Am. Heart J. 1984; 108:345-350.

7. Adebiyi AA, Falase AO, Akenova YA. Left ventricular systolic function of Nigerians with sickle cell Anaemia. Tropical cardiology 1999;25/98:27-32.

8. Covit W, Espeland M, Gallagher D, Hillenbrand W, Leff S, Talner N. The heart in sickle cell anaemia. The co-operative study of sickle cell disease (CSSCD). Chest 1995;108(5):1214 - 1219. PubMed

9. Poludasu S, Ramkissoon K, Salciccioli L, Kamran H, Lazar JM. Left ventricular systolic function in sickle cell anaemia : a meta-analysis. J Card Fail 2013;19(5): 333 -41. PubMed

10. Sagawa K. The end- systolic pressure-volume relation of the ventricle; definition, modifications and clinical use. Circulation 1981;63:1223 - 1227. PubMed

11. Reichek N, Wilson J, Sutton MSJ, Plappert TA, Goldberg S, Hirshfeld JW. Noninvasive Determination of Left Ventricular End-systolic Stress: Validation of the Method and Initial Application. Circulation. 1982;65(1): 99 -108. PubMed

12. Carabello BA, Nolan SP, McGuire LB. Assessment of Preoperative Left Ventricular Function in Patients with Mitral Regurgitation: Value of the End-systolic Wall Stress-End-systolic Volume Ratio. Circulation.1981; 64(6): 1212-1217. PubMed

13. Familusi JB, Adeyakunnu A.Geographical distribution and pathogenesis of the haemoglobinopathies. Dokita. 1980; 7:1-7.

14. Henry WL, Demaria A, Gramial R, et al. Report of the American society of echocardiography: Nomenclatureand standards in two dimensional echocardiography. Circulation. 1980;62: 212-217. 
15. Sahn DJ, Demaria A, Kislo J,et al. Recommendations regarding M-mode Echocardiography. Results of a survey of Echocardiographic measurements. Circulation 1978; 58:1072- 1083. PubMed

16. Grossman W, Jones D, McLaurin LP: Wall stress and patterns of hypertrophy in the human left ventricle. J Clin Invest 1975;56:56-64

17. Moran D, Epstein Y, Keren G, Laor A, Sherez J,
Shapiro Y. Calculation of mean arterial pressure during exercise as a function of heart rate. ApplHuman Sci. 1995;14:293-5. PubMed

18. Oguanobi NI, Ejim EC, Onwubere BJC, Ike SO, Anisiuba BC, Ibegbulam OG, Esi O. Effect of haematocrit on echocardiographic indices of cardiac dimension in sickle cell anaemia. Journal of College of Medicine 2011;16(2):39-47. 